\title{
REVIEW : GAMBARAN AKTIVITAS ENZIM ALKALINE PHOSPHATASE (ALP) PADA PEMAIN GAME ONLINE DI KECAMATAN JEKAN RAYA KOTA PALANGKA RAYA
}

\author{
Profile Of Alkaline Phosphatase (ALP) Activity In Online Game Players In District Of Jekan Raya \\ ${ }^{1}$ Oktavia Vivin Ermanita, Ria Agustina Handayani, Eki Muharamah, Dwi Purbayanti \\ 1,2 Department of Medical Laboratory Technology, Universitas Muhammadiyah Palangkaraya, Jl. RTA. \\ Milono Km. 1,5, Palangka Raya, Indonesia \\ *e-mail : oktavivinr31@yahoo.com
}

\begin{abstract}
ABSTRAK
Game online adalah suatu permainan yang dimainkan menggunakan jaringan internet. Game online dapat menyebabkan kecanduan yang mengakibatkan perubahan pola tidur yang dapat mengganggu irama sirkadian. Tubuh menjadi lebih banyak menghasilkan radikal bebas dan mengakibatkan stres oksidatif yang dapat menyerang sel hepatosit. Untuk menilai kelainan pada fungsi hati salah satunya dapat diketahui dengan melakukan pemeriksaan enzim Alkaline Phospatase (ALP). Tujuan penelitian ini ialah untuk mengetahui gambaran aktivitas enzim Alkaline Phospatase (ALP) pada pemain game Online di kota Palangka Raya. Penelitian ini dilakukan dengan metode deskriptif menggunakan teknik Snowball Sampling dan sampel dalam penelitian ini berjumlah 50 orang. Dari hasil pemeriksaan aktivitas enzim Alkaline Phosphatase (ALP) diperoleh nilai ALP diatas normal 10 orang $(20 \%)$.
\end{abstract}

Kata kunci : Alkaline Phospatase (ALP), Pemain Game Online

\section{ABSTRACT}

Online game is a game that is played using an internet network. Online games can cause addictions which result in changes in sleep patterns that can disrupt circadian rhythms. The body produces more free radicals and causes oxidative stress which can attack hepatocyte cells. To assess abnormalities in liver function one of them can be known by checking the enzyme Alkaline Phosphatase (ALP). The purpose of this study was to determine the activity of the Alkaline Phosphatase (ALP) enzyme in Online game players in the city of Palangka Raya. This research was conducted with a descriptive method using the Snowball Sampling technique and the sample in this study amounted to 50 people. From the results of the examination of the activity of the enzyme Alkaline Phosphatase (ALP) ALP values obtained above normal 10 people (20\%).

Keyword : Alkaline Phospatase (ALP), Game Online Players

\section{PENDAHULUAN}

Game online adalah suatu permainan yang dimainkan di komputer dan dilakukan secara online (melalui internet) dan bisa dimainkan oleh banyak orang secara bersamaan (Kurniawan, 2017). Game online akan berdampak positif apabila dimanfaatkan untuk hiburan, di mana segala rasa penat dan stres dapat dikurangi dengan bermain game. Namun saat ini, game online banyak dimainkan secara berlebihan yang dapat berdampak buruk terhadap dirinya pribadi, keluarga, sosial, pendidikan, pekerjaan dan kesehatan (Novrialdy, 2019).

Surbakti (2017) melaporkan sebuah kasus kecanduan game online di Negara Rusia tahun 2015, dimana seorang remaja berusia 17 tahun meninggal akibat terlalu sering bermain game online selama 22 hari tanpa henti.

Remaja dianggap lebih sering dan lebih rentan terhadap kecanduan game online daripada orang dewasa. Masa remaja yang berada pada periode ketidakstabilan, cenderung lebih mudah terjerumus terhadap percobaan hal-hal baru, remaja yang sudah kecanduan bermain game online akan memiliki kualitas tidur yang buruk 
(Latifatul, 2018). Berdasarkan penelitian dari Chen dan Gau (2014) pada anak-anak dan remaja menunjukkan bahwa kecanduan internet berhubungan dengan berkurangnya kualitas durasi tidur pada malam hari. Villafuerte et al (2015) mengatakan bahwa kurang tidur mempengaruhi banyak fungsi fisiologi, termasuk organ sekresi hormon, kemampuan kognitif, memori dan fungsi kekebalan tubuh. Bukti klinis menunjukkan bahwa kurang tidur dapat meningkatkan stress oksidatif (Villafuerte et al., 2015). Menurut Cichoz-Lach \& Michalak (2014) Stres oksidatif dapat menghasilkan kelainan pada struktural dan fungsional di hati.

Sutanto et al (2013) mengatakan bahwa ketika tidur, di dalam tubuh manusia terjadi berbagai proses biologis yang sangat penting bagi kesehatan. Saat tidur, terjadi proses detoksifikasi pada tubuh, serta proses restoratif yang memperbaiki kerusakankerusakan yang terjadi pada sel-sel tubuh setelah beraktivitas.

Menurut Rosa et al (2011) menyatakan bahwa apabila kebutuhan tidur tidak terpenuhi maka akan terganggu metabolisme, sehingga mengakibatkan terganggunya (jam biologis tubuh) irama sirkadian sehingga tubuh lebih banyak menghasilkan radikal bebas yang dapat mengakibatkan stress oksidatif sehingga dapat menyerang sel hepatosit.

Hati adalah organ yang paling kompleks pada manusia seperti yang diberikan untuk membentuk sejumlah fungsi metabolik penting yang berbeda. Selain detoksifikasi zat beracun, hati ini juga memproduksi protein dan hormon. Fungsi lain dari hati yaitu untuk pembekuan darah, mengontrol gula darah, dan membunuh kuman (Dafriani, 2019). Selain itu hati juga berfungsi sebagai ekskresi dan detoksifikasi senyawa racun dari dalam tubuh (Bishop et al., 2010). Adanya kelainan pada fungsi hati dapat diketahui dengan melakukan pemeriksaan enzim hati yaitu enzim aspartat aminotransferase (AST), alanin aminotransferase (ALT), gammaglutamil transferase (GGT) dan alkaline phosphatase (ALP).

ALP merupakan enzim yang digunakan untuk menilai kelainan hepatoseluler dan hepatobilier. Enzim ini terdapat di tulang, hati, dan plasenta. ALP di sel hati terdapat di sinusoid dan membran saluran empedu, selain itu ALP banyak dijumpai pada aktivitas osteoblast. Rosida (2016) menyatakan nilai normal lebih tinggi pada anak anak, wanita hamil dan pada cidera tulang. Peningkatan nilai ALP yang tinggi dapat menunjukkan bahwa saluran empedu terhambat. Peningkatan kadar 1x dari nilai normal bisa disebabkan oleh hepatobillier dan tulang. Peningkatan kadar 4x dari nilai normal mengarah pada kelainan hepatobilier Peningkatan kadar 3x dapat dijumpai pada penyakit hati (hepatitis dan sirosis). Peningkatan kadar hingga 10x dapat dijumpai pada obstruksi saluran empedu. Selain itu Bishop et al (2010) menyatakan kenaikan nilai ALP yang tidak normal dapat menunjukkan adanya penyakit hati atau tulang.

\section{METODE PENELITIAN}

Penelitian ini menggunakan metode deskriptif yaitu suatu penelitian yang dilakukan untuk memberikan gambaran atau mendeskripsikan tentang suatu keadaan objektif lalu diuraikan. Penelitian ini menggambarkan kadar enzim alkaline phosphatase (ALP) pada pemain game online di Kecamatan Jekan Raya Kota Palangka Raya.

\section{PEMBAHASAN}

Penelitian ini dilakukan di laboratorium Kimia Klinik Universitas Muhammadiyah Palangkaraya. Pengambilan sampel dilakukan pada bulan maret-juni di kecamatan Jekan Raya, kota Palangka Raya.

Karakteristik responden berdasarkan Usia, Durasi Tidur, Durasi Bermain Game, Aktivitas Merokok, Tekanan Darah, dan Indeks Massa Tubuh (IMT) sebagaimana disajikan pada tabel 1.

Tabel 1. Karakteristik Responden pemain game online di kecamatan Jekan Raya

\begin{tabular}{|l|r|c|}
\hline \multirow{2}{*}{ Karakteristik Responden } & \multicolumn{2}{|c|}{ Frekuensi N = 50 } \\
\cline { 2 - 3 } & Jumlah & Persentase (\%) \\
\hline Usia (tahun) : & & \\
$19-22$ & 34 & 68,0 \\
$23-26$ & 16 & 32,0 \\
\hline Durasi Tidur (jam/hari): & & \\
$<7$ & 43 & 86,0 \\
$7-9$ & 7 & 14,0 \\
& & \\
\hline $\begin{array}{l}\text { Durasi Bermain Game } \\
\text { (jam/hari): }\end{array}$ & 46 & 92,0 \\
4-8 & & 8,0 \\
\hline 8 & 4 & 38,0 \\
\hline Aktivitas Merokok: & & \\
Merokok & 19 & \\
Tidak Merokok & & \\
\hline
\end{tabular}




\begin{tabular}{|c|c|c|}
\hline & 31 & 62,0 \\
\hline $\begin{array}{l}\text { Tekanan Darah: } \\
\text { Normal } \\
\text { Pre hipertensi } \\
\text { Hipertensi }\end{array}$ & $\begin{array}{c}32 \\
16 \\
2\end{array}$ & $\begin{array}{c}64,0 \\
32,0 \\
4,0\end{array}$ \\
\hline $\begin{array}{lll}\text { Indeks } & \text { Massa } & \text { Tubuh } \\
\text { (IMT): } & & \\
\text { Kurus } & & \\
\text { Normal } & & \\
\text { Gemuk } & & \\
\end{array}$ & $\begin{array}{c}3 \\
42 \\
5\end{array}$ & $\begin{array}{l}6,0 \\
84,0 \\
10,0\end{array}$ \\
\hline
\end{tabular}

Berdasarkan Tabel 1, Karakteristik

berdasarkan usia, diperoleh jumlah reponden terbanyak usia 19-22 tahun, (68\%) 34 orang. Berdasarkan durasi tidur diperoleh jumlah responden terbanyak pada kelompok durasi tidur $<7$ jam, $(86 \%)$ 43 orang. Berdasarkan durasi lama bermain game diperoleh jumlah responden terbanyak pada 4-8 jam, (92\%) 46 orang. Berdasarkan karakteristik merokok diperoleh jumlah responden terbanyak pada tidak merokok (62\%) 31 orang. Berdasarkan tekanan darah diperoleh jumlah responden terbanyak pada tekanan darah normal (64\%) 32 orang. Berdasarkan IMT diperoleh jumlah responden terbanyak pada IMT normal (84\%) 42 orang.

Tabel 2. Gambaran Nilai ALP berdasarkan usia pada pemain game online di Jekan Raya tahun 2019

\begin{tabular}{|l|c|c|c|c|c|}
\hline \multirow{4}{*}{$\begin{array}{c}\text { Usia } \\
\text { (Tahun) }\end{array}$} & \multicolumn{4}{|c|}{ Kadar ALP } & \multirow{2}{*}{$\begin{array}{c}\text { Rerata } \pm \text { SD } \\
\text { Kadar ALP } \\
\text { (U/L) }\end{array}$} \\
\cline { 2 - 5 } & \multicolumn{2}{|c|}{ Normal } & \multicolumn{2}{|c|}{ Meningkat } & \\
\cline { 2 - 5 } & $\mathbf{n}$ & $\mathbf{\%}$ & $\mathbf{n}$ & $\boldsymbol{\%}$ & \\
\hline $19-22$ & 26 & 65,0 & 8 & 80,0 & $96,5 \pm 32,3$ \\
\hline $23-26$ & 14 & 35,0 & 2 & 20,0 & $34,8 \pm 32,3$ \\
\hline
\end{tabular}

Berdasarkan tabel 2, hasil pemeriksaan ALP yang telah dilakukan, karakteristik usia $19-22$ tahun diperoleh nilai rerata ALP (96,5\%). Ditemukan hasil diatas nilai normal berjumlah 8 orang $(80,0 \%)$. Peningkatan ALP dalam serum disebabkan osteoblast (pertumbuhan sel sel tulang), anak yang tulangnya sedang tumbuh memiliki kadar ALP tulang yang tinggi. Demikian juga dengan orang dewasa yang sedang mengalami penyembuhan patah tulang (Program et al., 2017). Menurut Badan Kependudukan dan Keluarga Bencana (BKKBN) rentang usia remaja adalah 10-24 tahun dan belum menikah (Pusdatin, 2017).

Hasil ini sejalan dengan penelitian yang dilakukan oleh Wilcox (2015) bahwa kadar ALP serum sangat tinggi pada Remaja dan menurun pada orang dewasa. Hal ini disebabkan oleh perbedaan dalam pembentukan tulang.

Tabel 3. Gambaran Aktivitas Enzim Alkaline Phosphatase (ALP) berdasarkan Durasi Tidur pada Pemain Game Online di kecamatan Jekan Raya

\begin{tabular}{|c|c|c|c|c|c|}
\hline \multirow{2}{*}{$\begin{array}{c}\text { Durasi } \\
\text { Tidur } \\
\text { (jam/hari) }\end{array}$} & \multicolumn{4}{|c|}{ Kadar ALP } & \multirow{2}{*}{$\begin{array}{c}\text { Rerata } \pm \text { SD } \\
\text { Kadar ALP } \\
\text { (U)/L) }\end{array}$} \\
\cline { 2 - 5 } & \multicolumn{2}{|c|}{ Normal } & \multicolumn{2}{|c|}{ Meningkat } & \\
\cline { 2 - 5 } & $\mathbf{n}$ & $\%$ & $\mathbf{n}$ & $\%$ & \\
\hline$<7$ & 34 & 85,0 & 9 & 90,0 & $90.6 \pm 35.4$ \\
\hline $7-9$ & 6 & 15,0 & 1 & 10 & $101.8 \pm 17.3$ \\
\hline
\end{tabular}

Berdasarkan tabel 3, hasil pemeriksaan ALP yang telah dilakukan menurut karakteristik durasi tidur $<7$ jam, ditemukan hasil diatas nilai normal berjumlah 9 orang $(90,0 \%)$ meskipun nilai rerata terbanyak adalah $(101,8)$. Pemain game online seharusnya membutuhkan waktu tidur 7-8 jam/hari. Akan tetapi, karena aktivitas bermain game yang berlebihan dapat menyebabkan kelelahan dan kehilangan jam tidur yang seharusnya. Pikir, et al., (2013) menyatakan bahwa aktivitas bermain game yang berlebihan dapat menyebabkan terganggunya ritme sirkadian, kelelahan, dan kurang tidur.

Hasil ini sejalan dengan penelitian yang dilakukan oleh Rosa et al. (2011) apabila kebutuhan tidur tidak terpenuhi maka akan berakibat pada terganggunya metabolisme, yang mengakibatkan terganggunya jam biologis tubuh (irama sirkadian) sehingga tubuh lebih banyak menghasilkan radikal bebas yang dapat mengakibatkan stress oksidatif sehingga dapat menyerang sel hepatosit.

Tabel 4. Gambaran Aktivitas Enzim Alkaline Phosphatase (ALP) berdasarkan Durasi Bermain Game pada Pemain Game Online di kecamatan Jekan Raya

\begin{tabular}{|c|c|c|c|c|c|}
\hline \multirow{2}{*}{$\begin{array}{c}\text { Durasi } \\
\text { Bermain } \\
\text { Game } \\
\text { (jam/hari) }\end{array}$} & \multicolumn{4}{|c|}{ Kadar ALP } & \multirow{2}{*}{$\begin{array}{c}\text { Rerata } \pm \text { SD } \\
\text { Kadar ALP } \\
\text { (U/L) }\end{array}$} \\
\cline { 2 - 4 } & $\mathbf{2}$ & Normal & \multicolumn{2}{|c|}{ Meningkat } & \\
\cline { 2 - 5 } & $\mathbf{n}$ & $\mathbf{n}$ & $\%$ & \\
\hline $4-8$ & 38 & 95,0 & 8 & 80,0 & $90.1 \pm 30.5$ \\
\hline$>8$ & 2 & 5,0 & 2 & 20,0 & $112.3 \pm 39.2$ \\
\hline
\end{tabular}

Berdasarkan tabel 4, hasil pemeriksaan ALP yang telah dilakukan menurut karakteristik durasi lama bermain game $4-8$ jam ditemukan hasil diatas nilai normal berjumlah 8 orang $(80,0 \%)$. Meskipun nilai rerata terbanyak 112,3 U/L. Aktivitas bermain game yang berlebihan dapat memicu ketidakseimbangan produksi radikal bebas dengan antioksidan tubuh, yang disebut sebagai stress oksidatif. Stress oksidatif adalah suatu keadaan 
dimana produksi radikal bebas lebih banyak dari antioksidan sehingga menyebabkan kerusakan hati. Dimana hati tersebut berfungsi sebagai detoksifikasi racun yang penting bagi tubuh.

Hasil ini sejalan dengan penelitian yang dilakukan oleh Sri (2018) menunjukkan bahwa semakin tinggi kecanduan seseorang dalam bermain game online maka semakin tinggi juga kualitas tidur yang buruk yang didapatkan oleh pemain game online (Yuuhaa et al.,2018).

Tabel 5. Gambaran Aktivitas Enzim Alkaline Phosphatase (ALP) berdasarkan Aktivitas Merokok pada Pemain Game Online di kecamatan Jekan Raya

\begin{tabular}{|c|c|c|c|c|c|}
\hline \multirow{3}{*}{$\begin{array}{c}\text { Aktivitas } \\
\text { Merokok }\end{array}$} & \multicolumn{4}{|c|}{ Kadar ALP } & \multirow{2}{*}{$\begin{array}{c}\text { Rerata } \pm \text { SD } \\
\text { Kadar ALP } \\
\text { (U/L) }\end{array}$} \\
\cline { 2 - 5 } & \multicolumn{2}{|c|}{ Normal } & \multicolumn{2}{c|}{ Meningkat } & \\
\cline { 2 - 5 } & $\mathbf{n}$ & $\mathbf{1}$ & $\mathbf{n}$ & $\%$ & \\
\hline \multirow{2}{*}{ Perokok aktif } & & & & & \\
\hline \multirow{2}{*}{ Perokok pasif } & 15 & 37,5 & 4 & 40,0 & $88.1 \pm 28.1$ \\
\hline & 25 & 62,5 & 6 & 60,0 & $96.4 \pm 34.7$ \\
\hline
\end{tabular}

Berdasarkan tabel 5, hasil pemeriksaan ALP yang telah dilakukan menurut karakteristik tidak merokok, ditemukan hasil diatas nilai normal berjumlah 6 orang $(60,0 \%)$, dengan rerata nilai 96,4 U/L. Penelitian ini menunjukkan adanya peningkatan pada aktivitas enzim ALP pada responden yang tidak merokok.

Hasil ini sejalan dengan penelitian yang dilakukan oleh Program et al (2010) dimana ada hubungan antara aktivitas merokok dengan ALP karena didalam asap rokok terdapat banyak zat racun yang berbahaya bagi tubuh, salah satunya nikotin. Nikotin menyebabkan kadar lemak dalam darah meningkat, kondisi ini meningkatkan resiko munculnya gangguan fungsi hati.

Tabel 6. Gambaran Aktivitas Enzim Alkaline Phosphatase (ALP) berdasarkan Tekanan Darah pada Pemain Game Online di kecamatan Jekan Raya

\begin{tabular}{|c|c|c|c|c|c|}
\hline \multirow{2}{*}{$\begin{array}{c}\text { Tekanan Darah } \\
(\mathbf{m m H g})\end{array}$} & \multicolumn{4}{|c|}{ Kadar ALP } & \multirow{2}{*}{$\begin{array}{c}\text { Rerata } ~ \\
\text { Kadar SD } \\
\text { (U/L) }\end{array}$} \\
\cline { 2 - 5 } & \multicolumn{3}{|c|}{ Normal } & \multicolumn{2}{|c|}{ Meningkat } \\
\cline { 2 - 5 } & $\mathbf{n}$ & $\%$ & $\mathbf{n}$ & $\%$ & \\
\hline Normal & 26 & 65,0 & 6 & 60,0 & $90.6 \pm 35.4$ \\
\hline Pre hipertensi & 13 & 32,5 & 3 & 30,0 & $101.8 \pm 17.3$ \\
\hline Hipertensi & 1 & 2,5 & 1 & 10,0 & 67 \\
\hline
\end{tabular}

Berdasarkan tabel 6, hasil pemeriksaan ALP yang telah dilakukan menurut karakteristik tekanan darah normal ditemukan hasil diatas nilai normal berjumlah 6 orang $(60,0 \%)$ meskipun rerata nilai terbanyak adalah 101,8 U/L. Penelitian ini menunjukkan adanya peningkatan aktivitas enzim ALP pada kategori tekanan darah normal.

Hasil ini tidak sejalan dengan penelitian yang dilakukan oleh Rahman et al (2020) dimana peningkatan kadar enzim hati lebih tinggi pada orang dengan hipertensi. Mereka juga mengemukakan bahwa peningkatan serum ALP secara positif berhubungan dengan hipertensi pada orang dewasa di Bangladesh.

Tabel 7. Gambaran Aktivitas Enzim Alkaline Phosphatase (ALP) berdasarkan Indeks Massa Tubuh (IMT) pada Pemain Game Online di kecamatan Jekan Raya

\begin{tabular}{|c|c|c|c|c|c|}
\hline \multirow{4}{*}{$\begin{array}{l}\text { Indeks Massa } \\
\text { Tubuh (IMT) }\end{array}$} & \multicolumn{4}{|c|}{ Kadar ALP } & \multirow{4}{*}{$\begin{array}{l}\text { Rerata } \pm \text { SD } \\
\text { Kadar ALP } \\
\text { (U/L) }\end{array}$} \\
\hline & \multicolumn{4}{|c|}{$\mathbf{N}=\mathbf{5 0}$} & \\
\hline & \multicolumn{2}{|c|}{ Normal } & \multicolumn{2}{|c|}{ Meningkat } & \\
\hline & $\mathrm{n}$ & $\%$ & $\mathbf{n}$ & $\%$ & \\
\hline Kurus & 3 & 7,5 & 0 & 0 & $79.3 \pm 8,5$ \\
\hline Normal & 33 & 82,5 & 9 & 90,0 & $90.3 \pm 34.2$ \\
\hline Gemuk & 4 & 8 & 1 & 10,0 & $103.4 \pm 31.9$ \\
\hline
\end{tabular}

Berdasarkan tabel 7, hasil pemeriksaan ALP yang telah dilakukan menurut karakteristik IMT normal ditemukan hasil diatas nilai normal berjumlah 9 orang $(90,0 \%)$ meskipun dengan nilai rerata terbanyak 103,4 U/L. Penelitian ini menunjukkan adanya peningkatan aktivitas enzim ALP pada responden dengan kategori IMT normal.

Hasil ini sejalan dengan penelitian yang dilakukan oleh Kelishadi et al., (2009) bahwa remaja dengan kelebihan berat badan/obesitas lebih banyak mengalami peningkatan kadar AST, ALT, dan ALP daripada remaja yang memiliki berat badan normal.

Gambaran Aktivitas Enzim Gamma Glutamyl Transferase (GGT) pada pemain game online di kecamatan Jekan Raya sebagaimana disajikan pada diagram 1. 


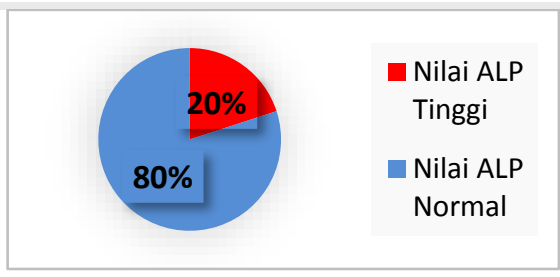

Diagram 1. Gambaran Aktivitas Enzim ALP (Alkaline phosphatase)

Berdasarkan hasil pemeriksaan dari nilai ALP pada sampel pemain game online $80 \%$ (40 orang) memiliki nilai ALP normal dan 20\% (10 orang) memiliki nilai ALP diatas nilai normal.

Nilai ALP diatas normal pada 10 orang $(20 \%)$ ini setelah dilihat pada data hasil pemeriksaan GGT sebagai data sekunder, didapatkan nilai GGT pada pemain game online tersebut normal. Pemeriksaan ALP seringkali diukur bersamaan dengan pemeriksaan enzim lainnya seperti GGT. Jika nilai ALP meningkat disertai nilai GGT meningkat diduga terjadi gangguan hepatobillier sedangkan jika nilai ALP meningkat dan GGT normal mengarah kepada penyakit tulang yang dapat berasal dari usus, ginjal dan plasenta atau hal ini dapat disebabkan karena usia responden dalam penelitian ini berada dalam rentang 19-26 tahun, menurut Badan Kependudukan dan Keluarga Bencana (BKKBN) rentang usia remaja adalah 10-24 tahun dan belum menikah. Peningkatan ALP dalam serum disebabkan osteoblast (pertumbuhan sel-sel tulang), yang tulangnya sedang tumbuh memiliki kadar ALP tulang yang tinggi. Demikian juga dengan orang dewasa yang sedang mengalami penyembuhan patah tulang (Rosida, 2016).

ALP merupakan enzim yang digunakan untuk menilai kelainan hepatoseluler dan hepatobilier. ALP di sel hati terdapat di sinusoid dan membran saluran empedu, selain itu ALP banyak dijumpai pada aktivitas osteoblast. Levelnya signifikan lebih tinggi pada anak anak, wanita hamil dan pada cidera tulang (Rosida, 2016).

Peningkatan ALP tulang dalam serum terjadi sebagai bagian dari respon pertumbuhan osteoblastik. Anak yang tulangnya sedang tumbuh memiliki kadar ALP tulang yang tinggi. Demikian juga orang dewasa yang sedang mengalami penyembuhan patah tulang (Program et al., 2017).

Level ALP tinggi menunjukkan bahwa saluran empedu terhambat. Peningkatan kadar $1 \mathrm{x}$ dari nilai normal bisa disebabkan oleh hepatobillier dan tulang. Peningkatan kadar $4 \mathrm{x}$ dari nilai normal mengarah pada kelainan hepatobilier, peningkatan kadar $3 \mathrm{x}$ dapat dijumpai pada penyakit hati (hepatitis dan sirosis). Peningkatan 5x dapat dijumpai pada ikterus kolestatik. Peningkatan kadar hingga 10x dapat dijumpai pada obstruksi saluran empedu. (Bishop et al., 2010). Kadar ALP serum dipengaruhi oleh beberapa faktor seperti: Umur, Jenis Kelamin, Terapi obat cairan dan bahan kimia, Kehamilan, Merokok, (Program et al., 2017).

\section{KESIMPULAN}

Dari penelitian gambaran aktivitas enzim Alkaline Phospatase (ALP) pada pemain game online di kecamatan Jekan Raya Kota Palangka Raya disimpulkan bahwa hasil pemeriksaan ALP dari 50 sampel pemain game onilne didapatkan (80\%) 40 orang memiliki nilai ALP norrnal dan 10 orang (20\%) memiliki nilai ALP diatas normal.

\section{DAFTAR PUSTAKA}

Adiningtiyas, S. W. 2017. Peran Guru Dalam Mengatasi Kecanduan Game Online. KOPASTA: Jurnal Program Studi Bimbingan Konseling, 4(1), 28-40.

Ambarwati, R. 2017. Tidur, Irama Sirkadian dan Metabolisme Tubuh. Jurnal Keperawatan, $X(1), 42-46$.

Bishop, M. L., Fody, E. P., \& Schoeff, L. E. 2010. Clinical Chemistry Techniques, Principles, Correlations. 6 th ed.

Cichoz-Lach, H., \& Michalak, A. (2014). Oxidative stress as a crucial factor in liver diseases. World Journal of Gastroenterology, 20(25), 8082-8091.

Dafriani, P. (2019). Anatomi \& Fisiologi. Jakarta:Penerbit Buku Kedokteran:EGC

Diani, A. W. (2014). Faktor-Faktor Yang Mempengaruhi Kecenderungan Kesulitan Tidur Pada Mahasiswa Yang Menyusun Skripsi. 2004. 
Edy Kurniawan, D. (2017). Pengaruh Intensitas Bermain Game Online Terhadap Perilaku Prokrastinasi Akademik Pada Mahasiswa Bimbingan Dan Konseling Universitas Pgri Yogyakarta. Jurnal Konseling GUSJIGANG, 3(1), 98.

Emadwiandr. (2013). Sifat Dan Peranan Enzim Bagi Makhluk Hidup. Journal of Chemical Information and Modeling, 53(9), 1689-1699.

Fahri, I. (2014). Hubungan Kebiasaan Bermain Game Online Pada Anak Usia Sekolah Dengan Kebutuhan Dasar Istirahat Dan Tidur di SD 060895. 6-25.

Goyena, R. (2019). kadar hemolisis pada serum mempengaruhi hasil pemeriksaan aktivitas enzim Gamma Glutamil Transferase. Journal of Chemical Information and Modeling, 53(9), 1689-1699.

Jaya, E. S. (2018). WHO tetapkan kecanduan game sebagai gangguan mental, bagaimana "gamer" Indonesia bisa sembuh? In The Conversation (Vol. 11, pp. 10-13).

Kelishadi, R., Cook, S. R., Adibi, A., Faghihimani, Z., Ghatrehsamani, S., Beihaghi, A., Salehi, H., Khavarian, N., \& Poursafa, P. 2009. Association of the components of the metabolic syndrome with non- alcoholic fatty liver disease among normal-weight, overweight and obese children and adolescents. Diabetology \& Metabolic Syndrome, 1(1).

Khan, S., Duan, P., Yao, L., \& Hou, H. 2018. Review Article Shiftwork-Mediated Disruptions of Circadian Rhythms and Sleep Homeostasis Cause Serious Health Problems. 2018.

Latifatul. 2018. Hubungan Kebiasaan Bermain Games Online Dengan Kualitas Tidur Remaja.103.

Masturoh, I. 2018. Metodologi Penelitian Kesehatan. 307.

Novrialdy, E. 2019. Kecanduan Game Online pada Remaja: Dampak dan Pencegahannya. Buletin Psikologi, 27(2), 148.

Program, M., Sebagai, P., Terapan, S. S., \& Susilaningsih, R. 2017. Perbandingan kadar alkali fosfatase (ALP) serum sebelum dan sesudah waktu tunda 4 dan 8 hari pada suhu kamar $\left(20-25^{\circ} \mathrm{C}\right)$.

Pusdatin. 2017. Infodatin Reproduksi RemajaEd.Pdf. In Situasi Kesehatan Reproduksi Remaja (p. 1).

Rahman, S., Islam, S., Haque, T., Kathak, R. R., \& Ali, N. 2020. Association between serum liver enzymes and hypertension: a cross-sectional study in Bangladeshi adults. BMC Cardiovascular Disorders, 20(1), 128.

Rosa, D. P., Martinez, D., Picada, J. N., Semedo, J. G., \& Marroni, N. P. 2011. Hepatic oxidative stress in an animal model of sleep apnoea: Effects of different duration of exposure. Comparative Hepatology, 10(1), 1.

Rosida, A. 2016. Pemeriksaan Laboratorium Penyakit Hati. Berkala Kedokteran, 12(1), 123.

Sutanto, I., Hartanto, D. D., Sn, S., Si, M., Sylvia, M., Sn, S., \& Petra, U. K. 2013. Perancangan Komunikasi Visual Iklan Layanan Masyarakat Kampanye Bahaya Kurang Tidur Terhadap Dewasa Muda Di Surabaya. 1, 1-10.

Tao, L., Li, X., Zhu, H., Gao, Y., Luo, Y., Wang, W., \& Wang, Z. 2013. Association between $\gamma$ Glutamyl Transferase and Metabolic Syndrome: A Cross-Sectional Study of an Adult Population in Beijing. 5523-5540.

Villafuerte, G., Miguel-Puga, A., Murillo Rodríguez, E., Machado, S., Manjarrez, E., \& AriasCarrión, O. 2015. Sleep deprivation and oxidative stress in animal models: A systematic review. In Oxidative Medicine and Cellular Longevity (Vol. 2015). Hindawi Publishing Corporation.

Yuuhaa, M. I. W. C., S, L. S., Bidang, P., Lingkungan, D., Amrullah, H., Law, A. O. F., Rahma, S. S., Mutiara, K., Murad, C., Baja, I., Utomo, K. S., Muryani, C., Nugraha, S., Sjafei, I., Kota, D. I., \& Selatan, T. 2018. Hubungan Kecanduan Bermain Game Online Dengan Kualitas Tidur. (Issue 2).

Wannamethee, S. G., \& Shaper, A. G. 2010. Cigarette smoking and serum liver. 104 
